ORIGINAL ARTICLE

\title{
肺癌における癌マーカーとしての尿中ジアセチルスペルミンの 臨床的意義
}

\author{
加藤雅人 $1 \cdot$ 大西秀哉 $2 \cdot$ 鈴木宏往 $2 \cdot$ \\ 鶴田伸子 $3 \cdot$ 樋口和行 $3 \cdot$ 片野光男 2
}

\section{The Clinical Significance of Urine Diacetylspermine Level as a Tumor Marker for Lung Cancer}

\author{
Masato Kato1; Hideya Onishi2; Hiroyuki Suzuki2; \\ Nobuko Tsuruta3; Kazuyuki Higuchi3; Mitsuo Katano2 \\ ${ }^{1}$ Department of Surgery, Hamanomachi General Hospital, Japan; ${ }^{2}$ Department of Cancer Therapy and Research, Graduate \\ School of Medical Sciences, Kyushu University, Japan; ${ }^{3}$ Department of Respiratory Medicine, Hamanomachi General Hospital, \\ Japan.
}

\begin{abstract}
Objective. The aim of the present study was to define the usefulness of a urine tumor marker, diacetylspermine (DiAcSpm) in patients with lung cancer. Materials and Methods. Of the patients who were treated for lung cancer from August 2003 to September 2010 in our hospital, 308 (non-small cell lung cancer-296, small cell lung cancer-12) were enrolled in this study. We compared the urine tumor marker, DiAcSpm with serum tumor markers (CEA, CYFRA21-1 and Pro-GRP). Results. The sensitivity of urine DiAcSpm (46.4\%) was significantly higher than that of serum CEA (32.7\%) and serum CYFRA21-1 (23.7\%). The specificity of urine DiAcSpm (90.6\%) was similar to that of serum CEA (87.5\%) and serum CYFRA21-1 (93.8\%). We then compared the sensitivities of DiAcSpm and other markers among subjects according to tumor stage. The sensitivity of DiAcSpm was higher than that of CYFRA21-1 in Stage IA and IB patients, and CEA in Stage IIIB and IV patients, while the proportion of positive results for each marker increased with progression of the cancer. In particular, DiAcSpm was markedly elevated in $25.5 \%$ and $42.6 \%$ of Stage IA and IB patients, respectively, whereas only $5.4 \%$ and $18.5 \%$ of these patients were CYFRA21-1-positive, respectively. Pathologically, the sensitivity of urine DiAcSpm was markedly higher in patients with adenocarcinoma (39.5\%) compared to CYFRA21-1 (17.3\%), and in squamous cell carcinoma $(62.0 \%)$ compared with CEA (33.3\%) and SCC antigen (49.0\%). Conclusion. These results suggest that urine DiAcSpm is useful as a tumor marker for lung cancer, because it is more sensitive than the serum markers currently in clinical use.
\end{abstract}

KEY WORDS — Diacetylspermine in urine, Tumor marker, Lung cancer

(JJLC. 2011;51:787-792)

Reprints: Masato Kato, Department of Surgery, Hamanomachi General Hospital, 3-5-27 Maizuru, Chuou-ku, Fukuoka 810-8359, Japan (e-mail: kato@hamanomachi.jp).

Received March 9, 2011; accepted October 3, 2011.

要旨一一目的. 尿中ジアセチルスペルミン（DiAcSpm） の肺癌における腫瘍マーカーとしての有用性を検討す る. 対象と方法. 2003 年 8 月より 2010 年 9 月までに当 院で治療を受けた肺癌の患者 308 例 (非小細胞癌 296 例,
小細胞癌 12 例) を対象とし, 尿中 DiAcSpm を測定した. 結果. 尿中 DiAcSpm は肺癌 308 例中 143 例で陽性 (46.4\%) を示し, 血清中の CEA の 32.7\%, CYFRA211 の $23.7 \%$ よ有意に高い敏感度を示した. 尿中
1国家公務員共済組合連合会浜の町病院外科; 2 九州大学大学院 医学研究院先端医療医学部門腫瘍制御学分野; 3国家公務員共済組 合連合会浜の町病院呼吸器内科.

別刷請求先 : 加藤雅人, 国家公務員共済組合連合会浜の町病院

\author{
外科, $\bar{\top} 810-8359$ 福岡市中央区舞 鶴 3-5-27(e-mail: kato@ \\ hamanomachi.jp). \\ 受付日：2011 年 3 月 9 日, 採択日：2011 年 10 月 3 日.
}


DiAcSpm の腫瘍マーカーとしての特異度（90.6\%）は, CEA $(87.5 \%)$, CYFRA21-1 (93.8\%) とほぼ同じであっ た. 肺癌の進行度別に各腫瘍マーカーを測定すると，進 行度とともに腫瘍マーカーの陽性率は増加したが, 尿中 DiAcSpm は Stage IA，IB において CYFRA21-1 と比較 し，また Stage IIIB および IV において CEA と比較し, 有意に高い陽性率を示した．特に, Stage IA および IB 患者における尿中 DiAcSpm 陽性率は, 各々 $25.5 \%$ およ び 42.6\% であり, 同 Stage の患者の CYFRA21-1 陽性率
(5.4\% および $18.5 \%)$ と比較し, 有意に高い陽性率を示し た。組織型別では尿中 DiAcSpm は，腺癌（39.5\%）で CYFRA21-1 (17.3\%) と比較し，また扁平上皮癌 (62.0\%) でCEA (33.3\%) および SCC 抗原 $(49.0 \%)$ と比較し有 意に高い陽性率を示した．結論．尿中 DiAcSpm は肺癌 の腫瘍マーカーとして高い敏感度を示し, 肺癌の腫瘍 マーカーとして有用であることが示唆された.

索引用語——尿中ジアセチルスペルミン, 腫瘍マー カー, 肺癌

\section{はじめに}

肺癌は他臓器癌に比べ早期診断が難しく罹患数, 死亡 数ともに増加の一途を辿っている。従来, 肺癌の診断に は主に胸部 X 線検査や喀痰細胞診が施行されてきたが, これらのみでは肺癌の早期診断は難しく, 最近では CT スキャンによる肺癌検診での早期発見に期待が高まって いる. 一方, 肺癌診断における腫瘍マーカーの役割につ いては現在のところ補助的と考えられている. 肺癌は他 臓器の癌と異なり多様な組織型を示すことが知られてい る.しかし, 現在, 臨床的に用いられている肺癌の腫瘍 マーカーは肺癌に対する感度および特異度において必ず しも十分とは言えず，より優れた腫瘍マーカーの開発が 望まれている。

ポリアミンとは多数のアミノ基を持つ低分子量のアル キルアミンの総称で, 細胞分裂時に細胞内に出現し, 役 割を果たしたポリアミンは細胞外に放出され, 肝臓でア セチル化されて尿中に排泄される．尿中ポリアミンは癌 患者で上昇することが 1970 年代に報告されていた。近 年, ポリアミンの代謝産物のなかで $\mathrm{N}^{1}, \mathrm{~N}^{12}$-ジアセチル スペルミン (以下略：DiAcSpm), $\mathrm{N}^{1}, \mathrm{~N}^{8}$-ジアセチルス ペルミジンという 2 種類のジアセチルポリアミンが尿中 に微量に排泄されることが見出され，特にDiAcSpm は 偽陰性が少なく, 癌の検出感度が高いこと, 治療効果を よく反映した動きを示すことが報告された。最近，この DiAcSpm の腫瘍マーカーとしての有用性が検討されて いるが, 今回, 我々は原発性肺癌患者の尿中 DiAcSpm 濃度を測定し, 肺癌における腫瘍マーカーとしての有用 性について検討した.

\section{対象および方法}

2003 年 8 月より 2010 年 9 月までに当院で治療を受け た肺癌の患者 308 例を対象とした．尿中 DiAcSpm の有 用性を検討するため, 従来の血清腫瘍マーカーである CEA，CYFRA21-1，Pro-GRP を同時に測定した．対象は
男性 199 例, 女性 109 例で, 年歯令は 25～89 歳 (66.9 10.4) であった。症例の内訳は手術不能症例を含む治療前肺癌 患者 308 例であり, 組織型別では腺癌 200 例, 扁平上皮 癌 71 例, 腺扁平上皮癌 13 例, 小細胞癌 12 例, その他 12 例であった. 肺癌の病期は本邦の肺癌取扱い規約（第 7 版）による Stage 分類で行い, Stage IA が 98 例, Stage IB 68 例, Stage IIA 12 例, Stage IIB 20 例, Stage IIIA 41 例, Stage IIIB 39 例, Stage IV 30 例であった（Table 1). 対照症例として肺癌術後の長期無再発症例 32 例 （1997 年 5 月から 2000 年 4 月までに手術を行い, 3 年以 上無再発経過中の症例）の測定を行った。検体は治療前 日までの早朝尿と血液を採取し，尿中 DiAcSpm は

Table 1. Patient Characteristics

\begin{tabular}{lcccc}
\hline $\begin{array}{l}\text { Patients with Lung Cancer } \\
\text { Controls* }\end{array}$ & $\begin{array}{l}308 \text { cases } \\
32 \text { cases }\end{array}$ & & \\
\hline Gender (male/female) & $199 / 109$ & & \\
Age, years (median) & $66.9 \pm 10.4$ & & \\
$\quad$ Range & $25-89$ & & & \\
Pathological stage & (Ad & SCC & SCLC & Others) \\
IA & $98(78$ & 15 & 1 & $4)$ \\
IB & $68(40$ & 25 & 1 & $2)$ \\
IIA & $12(5$ & 2 & 1 & $4)$ \\
IIB & $20(6$ & 9 & 1 & $4)$ \\
IIIA & $41(28$ & 9 & 1 & $3)$ \\
IIB & $39(21$ & 12 & 3 & $3)$ \\
IV & $30(20$ & 0 & 5 & $5)$ \\
Histologic type & & & & \\
Adenocarcinoma & 200 & & & \\
SCC & 71 & & & \\
Ad-SCC & 13 & & & \\
SCLC & 12 & & & \\
Others & 12 & & \\
\hline
\end{tabular}

* Patients without recurrence for more than 3 years after surgery for lung cancer.

SCC; Squamous cell carcinoma, Ad-SCC; Adenosquamous carcinoma, SCLC; Small cell carcinoma. 
Table 2. Urinary Diacetylspermine, Serum CEA and CYFRA21-1 in Lung Cancer Patients and Controls

\begin{tabular}{|c|c|c|c|c|c|c|}
\hline & \multicolumn{2}{|c|}{ Urinary diacetylspermine } & \multicolumn{2}{|c|}{ CEA } & \multicolumn{2}{|c|}{ CYFRA21-1 } \\
\hline & Positive & Negative & Positive & Negative & Positive & Negative \\
\hline Lung cancer & 143 & 165 & 100 & 206 & 66 & 212 \\
\hline Controls & 3 & 29 & 4 & 28 & 2 & 30 \\
\hline Sensitivity & \multicolumn{2}{|c|}{$46.4 \% *$} & \multicolumn{2}{|c|}{$32.7 \%$} & \multicolumn{2}{|c|}{$23.7 \%$} \\
\hline Specificity & \multicolumn{2}{|c|}{$90.6 \%$} & \multicolumn{2}{|c|}{$87.5 \%$} & \multicolumn{2}{|c|}{$93.8 \%$} \\
\hline
\end{tabular}

Note: $p$ values were obtained by McNemar test.

$* p=0.0153$ compared with CEA and $p=5.8521 \times 10^{-8}$ compared with CYFRA21- 1 .

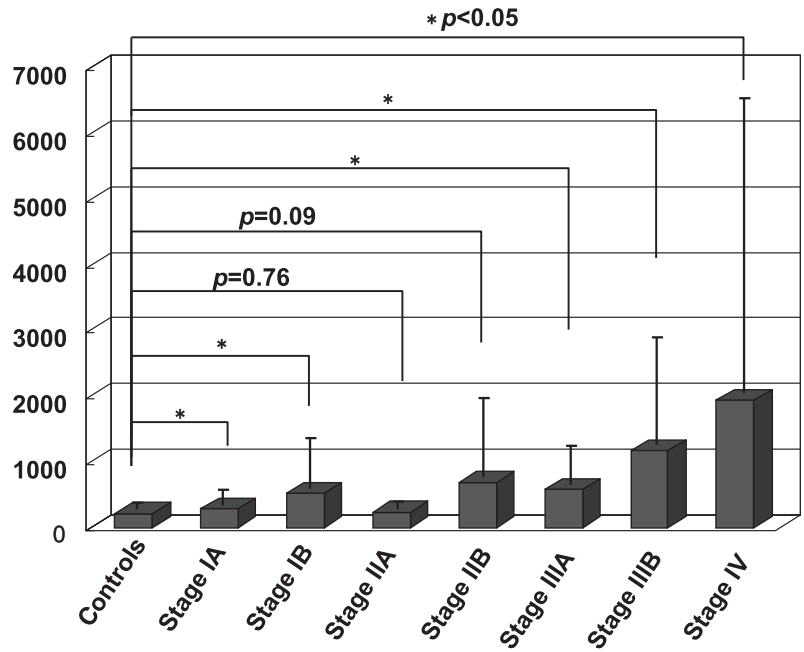

Figure 1. Urine DiAcSpm levels in non-small cell carcinoma according to clinical stage. Values are expressed as means \pm standard deviation (SD). ${ }^{*}, p<0.05$.

Alfresa Pharma 社製の金コロイド凝集法を用いて Alfresa Pharma 社で測定し，尿中クレアチニン值で除 し, 尿量, 腎機能を補正した. 尿中 DiAcSpm のカットオ フ值は Yamaguchi らの報告1 に従って $325 \mathrm{nmol} / \mathrm{g}$ ・ Creatinine とした．血清 CEA（正常值 $<5.0 \mathrm{ng} / \mathrm{ml}$ ）は CLEIA 法 (chemiluminescent enzyme immunoassay) で, 血清 CYFRA21-1（正常值 $<3.5 \mathrm{ng} / \mathrm{ml}$ ）は ECLIA 法 (electrochemiluminescence immunoassay)でまた Pro-GRP (正常值 $<45.9 \mathrm{pg} / \mathrm{ml}$ ) は CLEIA 法で測定した. 数值は平均土標準偏差で示し, 統計学的解析には McNemar 検定を用いた。危険率 $5 \%$ 未満を統計上有意 差ありとした．全症例，書面による informed consent を行い, 同意を得た。

\section{結 果}

\section{A. 肺癌患者における尿中 DiAcSpm と血清腫瘍マー カーの陽性率}

肺癌症例に扔いて尿中 DiAcSpm は，308 例中 143 例 において陽性 (陽性率 46.4\%) であった。一方，血清 CEA は陽性率 $32.7 \%$ であり，血清 CYFRA21-1 は 23.7\% で あった，尿中 DiAcSpm, 血清 CEA, CYFRA21-1 の肺癌 に対する特異度は $90.6 \%, 87.5 \%, 93.8 \%$ であった。これ らの結果より，尿中 DiAcSpm は敏感度においては CEA やCYFRA21-1 より有意に優っており, 特異度において は CEA，CYFRA21-1 と同等であった（Table 2).

\section{B. 非小細胞肺癌の Stage 別における尿中 DiAcSpm と 血清腫瘍マーカー}

非小細胞肺癌の進行度別での尿中 DiAcSpm は Stage IA, IB， IIA，IIB， IIIA，IIIB，IVで，それぞれ $294.2 \pm$ 224.5, 527.2 $\pm 743.3,236.6 \pm 107.7,697.9 \pm 1134.2,588.1 \pm$ $559.5,1178.2 \pm 1558.3,1948.4 \pm 4241.7 \mathrm{nmol} / \mathrm{g} \cdot$ Creatinine であり, Stage IIA と IIB 以外の各 Stage で有意 差をもって control 群（222.8 (Figure 1)。尿中 DiAcSpm, CEA, CYFRA21-1の各 Stage 別陽性率は Stage IA : 25.5\%, 18.6\%, 5.4\%, Stage IB : $42.6 \%, 32.3 \%, 18.5 \%$, Stage IIA : $33.3 \%, 16.7 \%$, $30.0 \%$, Stage IIB : $65.0 \%, 42.1 \%, 25.0 \%$, Stage IIIA : $51.2 \%, 39.0 \%, 26.3 \%$, Stage IIIB : 66.7\%, 53.8\%, 56.3\%, Stage IV : 83.3\%, 43.3\%, 58.3\% であり，尿中 DiAcSpm 值は, Stage IA，IB に打いて CYFRA21-1 と比較しまま た Stage IIIB，IV において CEA と比較し高い陽性率を 示した. Stage IA と IBでは CYFRA21-1 に対して高い 陽性率を示していることょり，尿中 DiAcSpm 值は肺癌 の IA，IB 期の補助診断に有用であると考えられた（Table 3). 肺癌は組織学的多様性を有するため, 今回の症例 で最も症例の多かった腺癌において Stage 別検討を行っ たところ，尿中 DiAcSpm 陽性率は Stage IA および IB において CYFRA21-1 と比較し有意に高い陽性率を示し 
Table 3. Tumor Stage and Urinary Diacetylspermine, Serum CEA and CYFRA21-1 by Lung Cancer Stage

\begin{tabular}{lcccccc}
\hline & \multicolumn{3}{c}{ Urinary diacetylspermine } & & CEA & \multicolumn{2}{c}{ CYFRA21-1 } \\
\cline { 2 - 4 } \cline { 6 - 7 } & Positive & Negative & Sensitivity (\%) & & \multicolumn{2}{c}{ Sensitivity (\%) } \\
\hline Stage IA & 25 & 73 & $25.5^{*}$ & & 18.6 & 5.4 \\
Stage IB & 29 & 39 & $42.6^{\dagger}$ & & 32.3 & 18.5 \\
Stage IIA & 4 & 8 & 33.3 & & 16.7 & 30.0 \\
Stage IIB & 13 & 7 & 65.0 & & 42.1 & 25.0 \\
Stage IIIA & 21 & 20 & 51.2 & & 39.0 & 26.3 \\
Stage IIIB & 26 & 13 & $66.7^{\ddagger}$ & & 53.8 & 56.3 \\
Stage IV & 25 & 5 & $83.3^{\S}$ & & 43.3 & 58.3 \\
\hline
\end{tabular}

Note: $p$ values were obtained by McNemar test.

${ }^{*} p=0.0005$ compared with CYFRA21-1, ${ }^{\dagger} p=0.0037$ compared with CYFRA21- $1,{ }^{*} p=0.0133$ compared with CEA, ${ }^{\S} p=0.0133$ compared with CEA.

Table 4. Tumor Stages in Adenocarcinoma Patients and Urinary Diacetylspermine, Serum CEA and CYFRA21-1 Levels

\begin{tabular}{lcccccc}
\hline & \multicolumn{3}{c}{ Urinary diacetylspermine } & & CEA & \multicolumn{2}{c}{ CYFRA21-1 } \\
\cline { 2 - 4 } \cline { 6 - 7 } & Positive & Negative & Sensitivity (\%) & & \multicolumn{2}{c}{ Sensitivity (\%) } \\
\hline Stage IA & 21 & 59 & $26.3^{*}$ & & 15.0 & 3.9 \\
Stage IB & 13 & 27 & $32.5^{\dagger}$ & & 32.5 & 8.3 \\
Stage IIA & 0 & 5 & 0 & & 20.0 & 0 \\
Stage IIB & 4 & 2 & 66.7 & & 66.7 & 20.0 \\
Stage IIIA & 13 & 15 & 46.4 & & 44.4 & 23.1 \\
Stage IIIB & 11 & 10 & 52.4 & & 57.1 & 55.6 \\
Stage IV & 18 & 2 & $90.0^{\ddagger}$ & & 50.0 & 75.0 \\
\hline
\end{tabular}

Note: $p$ values were obtained by McNemar test.

${ }^{*} p=0.0001211$ compared with CYFRA21-1, ${ }^{\dagger} p=0.021270$ compared with CYFRA21-1, ${ }^{\ddagger} p=$ 0.00467 compared with CEA.

た.また尿中 DiAcSpm は Stage IV でCEA より有意に 高い陽性率を示したが，その他の Stage では CEA およ びCYFRA21-1 の陽性率とほほ同等であった(Table 4). さらに腺癌における TNM 別の検討では尿中 DiAcSpm の陽性率は, CEA の陽性率と比較し, M1 症例で有意に 高い陽性率を示し, また, CYFRA21-1 陽性率と比較して $\mathrm{T} 4, \mathrm{~N} 1, \mathrm{~N} 3, \mathrm{M} 1$ 症例以外の全例で有意に高い陽性率を 示した (Table 5).

\section{C. 肺癌の組織型と尿中 DiAcSpm と血清腫瘍マーカー}

肺癌の組織型別で検討したところ，尿中 DiAcSpm 值 は腺癌, 扁平上皮癌, 腺扁平上皮癌, 小細胞癌ではそれ ぞれ 434.1 $\pm 537.1 ， 800.7 \pm 1012.5 ， 538.8 \pm 426.9 ， 2052.1 \pm$ $3088.2 \mathrm{nmol} / \mathrm{g}$ ・Creatinine であり, 特に扁平上皮癌と小 細胞癌で高值を示した，組織型別での尿中 DiAcSpm の 陽性率は腺癌, 扁平上皮癌, 腺扁平上皮癌ではそれぞれ 39.5\%，62.0\%，53.8\% であり，CEAの 31.3\%，33.3\%, 15.4\%, CYFRA21-1 の 17.3\%, 47.6\%, 38.5\% に比してい
ずれの組織型でも陽性率が高い傾向を示した．特に尿中 DiAcSpm は, 腺癌では CYFRA21-1 と比較し, また扁平 上皮癌においては CEA および SCC 抗原と比較し有意 に高い陽性率を示した。一方，小細胞肺癌においても CEA の 41.7\% に対して尿中 DiAcSpm は $66.7 \%$ と陽性 率が高い傾向を示したが, 現在臨床で広く使用されてい る Pro-GRP の 88.9\% よりは陽性率が低い傾向であった (Table 6).

\section{考 察}

一般的に腫瘍マーカーとは, 癌細胞が血液や体液中に 産生するか, あるいは他の細胞が癌に反応して産生した 物質が検出され，それらが健常人や良性疾患の患者より も異常高值を示すものとして定義されており, 癌の補助 診断や治療効果判定の指標, 予後の予測や再発の検出に 利用されている。わが国において臨床的に使用されてい る腫瘍マーカーの多くは血清のマーカーであり, 肺癌 
Table 5. Tumor Stages in Adenocarcinoma Patients and Urinary Diacetylspermine, Serum CEA and CYFRA21-1 Levels

\begin{tabular}{|c|c|c|c|c|c|}
\hline & \multicolumn{3}{|c|}{ Urinary diacetylspermine } & CEA & CYFRA21-1 \\
\hline & Positive & Negative & Sensitivity (\%) & \multicolumn{2}{|c|}{ Sensitivity (\%) } \\
\hline $\mathrm{T} 1$ & 32 & 71 & $31.1 *$ & 21.4 & 8.5 \\
\hline $\mathrm{T} 2$ & 37 & 42 & $46.8^{\dagger}$ & 38.5 & 25.7 \\
\hline T3 & 6 & 2 & $75.0^{\ddagger}$ & 75.0 & 25.0 \\
\hline $\mathrm{T} 4$ & 5 & 5 & 50.0 & 40.0 & 50.0 \\
\hline N0 & 39 & 89 & $30.5^{\S}$ & 21.3 & 6.6 \\
\hline N1 & 8 & 10 & 44.4 & 44.4 & 26.7 \\
\hline $\mathrm{N} 2$ & 25 & 16 & $61.0 \|$ & 42.5 & 36.1 \\
\hline N3 & 8 & 5 & 61.5 & 76.9 & 58.3 \\
\hline M0 & 62 & 118 & $34.4^{\pi}$ & 30.3 & 12.1 \\
\hline M1 & 18 & 2 & $90.0^{\#}$ & 40.0 & 75.0 \\
\hline
\end{tabular}

Note: $p$ values were obtained by McNemar test.

$* p=0.00008$ compared with CYFRA21-1, ${ }^{\dagger} p=0.0093$ compared with CYFRA21-1, ${ }^{\ddagger} p=0.0455$ compared with CYFRA21-1, ${ }^{\S} p=0.0000059$ compared with CYFRA21-1, " $p=0.033895$ compared with CYFRA21-1, " $p=0.000002$ compared with CYFRA21-1, ${ }^{*} p=0.004678$ compared with CEA.

Table 6. Pathology and Urinary Diacetylspermine, Serum CEA and CYFRA21-1

\begin{tabular}{lcccc}
\hline & \multicolumn{4}{c}{ Urinary diacetylspermine } \\
\cline { 2 - 5 } & Adenocarcinoma & SCC & Ad-SCC & SCLC \\
\hline Positive & 79 & 44 & 7 & 8 \\
Negative & 121 & 27 & 6 & 4 \\
Sensitivity (\%) & $39.5^{*}$ & $62.0^{\dagger .} \neq$ & 53.8 & 66.7 \\
\hline CEA (\%) & 31.3 & 33.3 & 15.4 & 41.7 \\
CYFRA21-1 (\%) & 17.3 & 47.6 & 38.5 & 12.5 \\
SCC antigen (\%) & & 49.0 & & 88.9 \\
Pro-GRP (\%) & & & &
\end{tabular}

Note: $p$ values were obtained by McNemar test.

${ }^{*} p=1.906 \times 10^{-6}$ compared with CYFRA21-1, ${ }^{\dagger} p=0.014$ compared with CEA, ${ }^{*} p=0.0029$ compared with SCC antigen.

SCC; Squamous cell carcinoma, Ad-SCC; Adenosquamous carcinoma, SCLC; Small cell carcinoma.

マーカーとしては CEA, SLX, CA19-9, SCC 抗原, TPA, CYFRA21-1, NSE, Pro-GRP などがある.しかし肺癌は 多様な組織型を示すため, ただ 1 種類の腫瘍マーカーだ けでは満足する結果は得られず，数種類のマーカーが組 み合わされて臨床応用されている。今日，一般的には非 小細胞癌に対する第一選択の腫瘍マーカーとして CEA, CYFRA21-1, SCC 抗原が, また小細胞肺癌に対して ProGRP NSE が汎用されている. 2-4 今回測定したポリア ミンとは多数のアミノ基を持つ低分子量のアルキルアミ ンの総称であり，核酸やその他のアニオンとの相互作用 により蛋白合成や核酸合成の過程に関与することが知ら れているが, 5 その生理的機能はまだ十分には解明され ていない.しかし, 活発に増殖する組織にはポリアミン
が多量に含まれており, 細胞内で役割を果たしたそれら のポリアミンはアセチル体として細胞外に排出されるこ とから, 癌患者においてポリアミンの排泄量が増加する ことは容易に想像される. 文献的には, 1971 年に Russell が癌患者において尿中ポリアミンの排泄量が増加するこ とを最初に報告した. 6 その後多くの研究が行われたが, 当時は尿中ポリアミン全体を測定していたため, 偽陽性 例が相当数あり癌マーカーとしての有用性は否定されて いた.これは, 炎症を含む癌以外の病態でも細胞分裂の 克進により尿中ポリアミンの上昇がみられるためであっ た.しかし，1995 年に Hiramatsu らが尿中アセチルポリ アミンのうち, 微量に存在するジアセチルポリアミンの 測定法を確立して尿路悪性腫瘍の患者で測定した結果, 
DiAcSpm は癌に対し高感度で, しかも高特異度である ことが立証された. 7,8 その後, 膵癌や, 大腸癌, 乳癌など でも患者の尿中 DiAcSpm が高い頻度で上昇することが 報告されている.1,9

特に, 大腸癌では早期より高い陽性率を示すことが報 告されている. 9 本研究の目的は, 肺癌患者における尿中 DiAcSpm を測定し, 従来の血清マーカーの敏感度や, 特 異度などと比較検討することであったが, その結果, 肺 癌患者における尿中 DiAcSpm, CEA, CYFRA21-1 の敏 感度はそれぞれ $46.4 \%, 32.7 \%, 23.7 \%$ であり，従来の血 清マーカーより統計学的に高い敏感度を示した。また, 尿中 DiAcSpm, CEA, CYFRA21-1 の特異度はそれぞれ 90.6\%, 87.5\%, 93.8\% であり, CEA やCYFRA21-1 とほ ぼ同等であった，肺癌の組織型別に検討してみると，尿 中 DiAcSpm は非小細胞肺癌の代表的な組織型である腺 癌, 扁平上皮癌, 腺扁平上皮癌のいずれの組織型におい ても従来の血清マーカーより陽性率が高い傾向を示し た。一方, 小細胞癌においては, 尿中 DiAcSpm(陽性率 は $66.7 \%$ ） は小細胞癌の特異的血清マーカーである ProGRP の 88.9\% よりはやや低い傾向であったが, CEA の $41.7 \%$ よりは陽性率が高い傾向を示した．肺癌の進行度 別の検討では，尿中 DiAcSpm は I 期の肺癌から高い陽 性率を示した。一般的に, 現在使用されている血清マー カーは進行癌では比較的高い陽性率を示すが, 他方, I 期肺癌においては陽性率が低いため, I 期肺癌に対して の補助診断としての有用性が低いと考えられている. 今 回の検討では, IA 期と IB 期で CYFRA21-1 がそれぞれ $5.4 \%$ と $18.5 \%$ の陽性率であったのに対して，尿中 DiAcSpm は $25.5 \%$ と $42.6 \%$ と有意に高い陽性率を示し た.この結果は, 尿中 DiAcSpm がI 期肺癌の補助診断に おいてはCEA と同等かそれ以上の有用性を示してお り, 胸部 X 線検査や喀痰検査では早期診断が難しい肺癌 のハイリスクグループにおけるスクリーニングや，検診 において有用な腫瘍マーカーである可能性を示してい る. 肺癌の組織型は多様性に富んでおり, Figure 1 の Stage IB, IIB, IIIA, IIIB 期で尿中 DiAcSpm の測定值 が高值を示したのは，これらの Stage において扁平上皮 癌の症例が多く含まれていた可能性がある。そこで今回 の検討で最も症例の多かった腺癌において進行度別の検 討を行ったところ, Stage II を除いて全ての Stage で CYFRA21-1 よりも陽性率が高い傾向を示し, CEA との 比較では Stage IV でCEA より有意に高い陽性率を示
した. 今回の検討では II 期の肺癌症例が少ないため, 統 計学的検討を行うことができなかったが, 今後症例を増 やして検討することによって, 肺癌における腫痬マー カーとしての尿中 DiAcSpm の有用性や, 化学療法など の治療効果の判定や予後予測, 再発診断における有用性 などが確立されることを期待する.

\section{まとめ}

尿中 DiAcSpm は肺癌症例において高い陽性率を示し た.また I 期肺癌症例でも従来の腫瘍マーカーより高い 陽性率を示したことから，尿中 DiAcSpm は肺癌の診断 やスクリーニングに有用な腫瘍マーカーであることが示 唆された.

本論文内容に関連する著者の利益相反：なし

\section{REFERENCES}

1. Yamaguchi K, Nakamura M, Shirahane K, Konomi H, Torata N, Hamasaki N, et al. Urine diacetylspermine as a novel tumour marker for pancreatobiliary carcinomas. Dig Liver Dis. 2005;37:190-194.

2. 河野修興. 呼吸器疾患と腫瘍マーカー. 日本内科学会雑 誌. 1999;88:141-147.

3. 仁保誠治, 新海 哲. 腫瘍マーカー. 肺癌. 癌と化学療法. 2001;28:2089-2093.

4. 六車博昭, 矢野聖二, 曽根三郎. 早期診断のために一肺癌 の腫瘍マーカーの読み方一. 臨牀と研究. 2005;82:224-228.

5. 五十嵐一衛. 神秘の生命物質一ポリアミン. 未来の生物科 学シリーズ 28. 東京 : 共立出版 ; 1993.

6. Russell DH. Increased polyamine concentrations in the urine of human cancer patients. Nat New Biol. 1971;233: 144-145.

7. Hiramatsu K, Sugimoto M, Kamei S, Hoshino M, Kinoshita K, Iwasaki K, et al. Determination of amounts of polyamines excreted in urine: demonstration of N1,N8diacetylspermidine and $\mathrm{N} 1, \mathrm{~N}$ 12-diacetylspermine as components commonly occurring in normal human urine. J Biochem. 1995;117:107-112.

8. Hiramatsu K, Sugimoto M, Kamei S, Hoshino M, Kinoshita K, Iwasaki K, et al. Diagnostic and prognostic usefulness of N1,N 8-diacetylspermidine and N1,N 12diacetylspermine in urine as novel markers of malignancy. J Cancer Res Clin Oncol. 1997;123:539-545.

9. Hiramatsu K, Takahashi K, Yamaguchi T, Matsumoto H, Miyamoto H, Tanaka S, et al. N1,N12-Diacetylspermine as a sensitive and specific novel marker for early- and late-stage colorectal and breast cancers. Clin Cancer Res. 2005;11:2986-2990. 